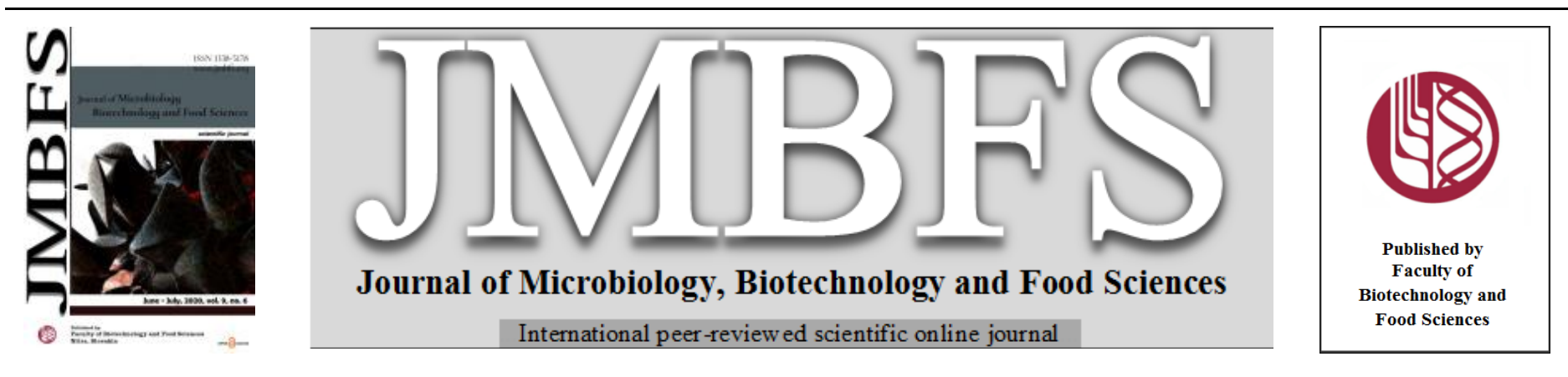

\title{
ANTIMICROBIAL ACTIVITIES OF GREEN SYNTHESIZED SILVER NANOPARTICLES FROM MARCHANTIA SP. EXTRACT: TESTING AN ALCOHOL-FREE HAND SANITIZER PRODUCT FORMULA
}

\author{
Fidia Fibriana*, Andin Vita Amalia, Siti Muntamah, Lindiya Ulva, Shaila Aryanti \\ Address(es): Fidia Fibriana, M.Sc. \\ Universitas Negeri Semarang, Faculty of Mathematics and Natural Sciences, Department of Integrated Science, Kampus Sekaran Gunungpati 50229 Semarang, \\ Indonesia.
}

*Corresponding author: fibriana.f@mail.unnes.ac.id

doi: $10.15414 / j m b f s .2020 .9 .6 .1034-1038$

\section{ARTICLE INFO}

Received 5. 7. 2019

Revised 10. 1. 2020

Accepted 10. 1.2020

Published 1. 6. 2020

Regular article

OPEN $\partial_{\text {ACCESS }}$

\begin{abstract}
Common liverwort is widely distributed around the world, and its extract has antibacterial, antifungal, and antiseptic activities. This research investigated the antimicrobial activity of biosynthesized silver nanoparticles (AgNPs) from common liverwort (Marchantia sp.) and its potency as a material for hand sanitizer formulation. The green synthesis (eco-friendly and biosafe synthesis using the nontoxic reagents) of liverwort AgNPs (LAgNPs) was performed using the maceration technique and $1 \mathrm{mg} \mathrm{AgNO}_{3}$. Characterization of LAgNPs was carried out using UV-Vis spectroscopy and Fourier Transform Infrared (FTIR) spectroscopy. Scanning Electron MicroscopyEnergy Dispersive X-ray (SEM-EDX) was performed to determine the nanoparticle size and elements. Then, the effectiveness of LAgNPs and LAgNPs-formulated hand sanitizer to inhibit the growth of Escherichia coli and Staphylococcus aureus was analyzed. The UV-Vis spectrophotometer results from LAgNPs at wavelength ranged from 400 to $700 \mathrm{~nm}$ shows an absorbance peak at $422 \mathrm{~nm}$. FTIR analysis indicates that the LAgNPs were stabilized by isothiocyanate and amide, which represents the presence of various phytochemicals in the liverwort extract. The SEM-EDX analysis clearly shows that the size of the nanoparticles lies between 0.020 $0.040 \mathrm{~nm}$, and it contains several elements $\mathrm{O}, \mathrm{C}, \mathrm{N}$, and Ag. Also, 75\% LAgNPs concentration inhibited the growth of E.coli and S.aureus with clear zone diameter at $19.75 \pm 6.13 \mathrm{~mm}$ and $16.25 \pm 0.54 \mathrm{~mm}$, respectively; whereas the formulated hand sanitizer inhibition diameter for both bacterial species was at $11.33 \pm 1.03 \mathrm{~mm}$ and $11.00 \pm 0.54 \mathrm{~mm}$, respectively. The LAgNPs exhibits a promising antimicrobial activity for application in a non-alcoholic hand sanitizer product formulation.
\end{abstract}

Keywords: antimicrobial activity; common liverwort; silver nanoparticles

\section{INTRODUCTION}

One of the most effective ways to protect the body from illnesses is good personal hygiene. The regular habit of bathing, teeth brushing, and hand washing before preparing or eating food and after going to the toilet are the form of good personal hygiene. Nowadays, people use the hand sanitizer as an additional application of a self-hygiene practice and also as a part of the lifestyle. Hand sanitizer is a liquid antiseptic generally used to kill infectious agents' on hands The use of hand sanitizers is also more practical than washing hands with soap, especially for people with high mobility and cannot find a hand-washer nearby. However, the main ingredient of most hand sanitizer products is alcohol, which can lead to skin irritation and dryness after a continuous application. Besides, the general continuous use of alcohol-based versions of hand sanitizers has no recommendations (Das et al., 2010; Desiyanto \& Djannah, 2013; Larson et al., 2006). Therefore, there is a need to formulate a non-alcohol based hand sanitizer using the natural sources which effective to kill microorganisms (Bolon, 2016).

Recently, researches on hand sanitizer formulations using natural extract have been carried out to obtain the most effective formula. Selvia et al. (2015) conducted a study of hand sanitizer gel preparations from rambutan fruit extract. They reported the antibacterial activity of the gel against Escherichia coli and Staphylococcus aureus. Dewi and Yunianto (2016) explained that the combination of kaffir lime extract and basil leaf extract produced an effective gel formulation as an antiseptic. Also, the use of coconut fiber with carbopol 940 gelling agent as a material for hand sanitizer was found to be effective in inhibiting the growth of E. coli, Pseudomonas aeruginosa, Salmonella thypi, Shigella dysenteriae, S. Aureus, and Vibrio sp. (Ismail et al., 2017). The results of these researches indicate that certain plants have the potential antibacterial activity for hand sanitizers' formulation.

Liverworts are known as the closest living relatives of the first land plants, which produce the flavonoids for coping with the abiotic stresses (Albert et al., 2018) As a natural source of flavonoid compounds, some species of liverworts have antipyretic, antihepatitic, and diuretic activities to cure wounds, fractures, burns, and snakebites (Asakawa, 2008). Marchantia is the common liverwort genus with many species that have been investigated for its potential activities agains pathogenic bacteria and fungi (Gahtori \& Chaturvedi, 2011; Mewari \& Kumar, 2009; Niu et al., 2006; Xiao et al., 2005). Even though the investigations of the antimicrobial activities of Marchantia spp. have been carried out, only a few studies have been conducted on the synthesis of silver nanoparticles from these species.

In recent years, the production of antimicrobial agents using silver nanoparticles (AgNPs) technology has been developed rapidly (Amooaghaie et al. 2015). The results of the study by Paosen et al. (2017) showed that AgNPs extract of Myrtaceae plants has excellent antibacterial activity against pathogenic bacteria such as Escherichia coli, Staphylococcus aureus, Enterococcus faecalis, Acinetobacter baumanii, Klebsiella pneumonia, and Pseudomonas aeruginosa.

In this research, the green synthesis of AgNPs from Marchantia sp. extract, characterization of Marchantia sp. AgNPs, formulation of hand sanitizer using Marchantia sp. silver nanoparticles were conducted. The green synthesis is a synthesis technique in the field of nanotechnology and provides economic and environmental benefits, which is a biocompatible process and generally can be accomplished by using a capping agent/stabilizer to control the size and prevent agglomeration using the plant extract. In this research, Marchantia sp. AgNPs were applied as the material, and its antibacterial profile against $E$. Coli and $S$. Aureus was performed. The research results could be used as the reference by manufacturers of antiseptic products or hand sanitizers to utilize common liverwort as the ingredient in their product formulation.

\section{MATERIALS AND METHODS}

\section{Materials}

Marchantia sp. used in this study was obtained from the area of Universitas Negeri Semarang, Indonesia. The identification of the species was performed based on the morphological characteristics by the plant taxonomy expert team 
from the Department of Biology, Universitas Negeri Semarang, Indonesia. Culture media were obtained from Oxoid Ltd. Part of Thermo Fisher Scientific Inc. (UK), chemical reagents were from Merck (Germany), Ajax Finechem (Australia), and RCI Labscan (Thailand). Silver nitrate $\left(\mathrm{AgNO}_{3}\right)$ was purchased from Sigma-Aldrich with $\geq 99.5 \%$ purity. The Escherichia coli and Staphylococcus aureus bacterial isolates for antibacterial testing in this research were obtained from the Laboratory of Biology Culture Collection, Universitas Negeri Semarang, Indonesia.

Liverwort Extract Preparation and Synthesis of Liverwort Silver Nanoparticles (LAgNPs)

Marchantia sp. samples were collected from the soil surface, and then, it was stored in sterile bottles and taken to the laboratory for further analysis. Liverwor was thoroughly washed with sterile distilled water, and then, it was shade dried at room temperature. Subsequently, the plants were ground into a fine powder using the electric blender. Next, the maceration method was performed by weighing 10 $\mathrm{g}$ of liverwort powder and mixing it with $100 \mathrm{ml}$ of ethanol for $24 \mathrm{~h}$ at room temperature. This technique was repeated three times in a gradual stage. The extraction process was continued by an evaporation technique using a hotplate in the open air and then filtering it with Whatman filter paper No.1. $\mathrm{AgNO}_{3}$ powder was dissolved in distilled water. The synthesis of LAgNPs was performed by adding $3 \mathrm{ml}$ liverwort extract in $40 \mathrm{ml}$ of $1 \mathrm{mg}$ silver nitrate $\left(\mathrm{AgNO}_{3}\right)$ solution for the reduction of $\mathrm{Ag}^{+}$ions. LAgNPs synthesis was made at room temperature (25 ${ }^{\circ} \mathrm{C} \pm 2{ }^{\circ} \mathrm{C}$ ) in a dark place for $24 \mathrm{~h}$ (Moteriya et al., 2014).

\section{Characterization of Liverwort Silver Nanoparticles (LAgNPs)}

The liverwort silver nanoparticles (LAgNPs) were characterized using the ultraviolet-visible (UV-Vis) spectroscopy analysis in the range of 400-700 nm. The characterization of LAgNPs functional groups was studied by Fourier Transform Infrared (FTIR) spectroscopy (FTIR PerkinElmer Spectrum Version 10.03.06) with spectrum at $4000-200 \mathrm{~cm}^{-1}$. The elemental composition of LAgNPs was investigated by the scanning electron microscope coupled to energy-dispersive X-ray spectroscopy (SEM-EDX) (Moteriya et al., 2014).

\section{Antimicrobial Test of Liverwort Silver Nanoparticles (LAgNPs)}

The antimicrobial activity of LAgNPs against pathogenic bacteria was evaluated by agar well diffusion method (Das et al., 2010). Gram-negative bacteria Escherichia coli and Gram-positive bacteria Staphylococcus aureus were prepared in nutrient broth at $37^{\circ} \mathrm{C}$ for $24 \mathrm{~h}$ with the density $2 \times 10^{6}$ cells $/ \mathrm{ml}$. The nutrient agar plate was prepared, and the surface was inoculated by spreading 20 $\mathrm{ml}$ of the microbial culture broth over the entire agar surface. Then, the hole with a diameter of $5 \mathrm{~mm}$ was made aseptically with a sterile cork borer. Subsequently, $50 \mu \mathrm{l}$ of LAgNPs in concentration at $25 \%, 50 \%, 75 \%$, and $100 \%$ were introduced to the well, and the plates were incubated at $37^{\circ} \mathrm{C}$ for $24 \mathrm{~h}$. Each concentration was tested in triplicates.

\section{Formulation of Liverwort Silver Nanoparticles (LAgNPs) Topical Gel}

LAgNPs hand sanitizer gel was prepared according to the method of gel formulation with the composition of extract at $6 \%(\mathrm{w} / \mathrm{w}), 5 \%(\mathrm{w} / \mathrm{w})$ sodium carboxymethylcellulose, $10 \%(\mathrm{w} / \mathrm{w})$ glycerol, $5 \%(\mathrm{w} / \mathrm{w})$ propylene glycol, and water up to $100 \%$. The most effective concentration of LAgNPs obtained from the antimicrobial activity was measured depending on the needed amount volume of water and then added to $5 \%$ of the base. Glycerol and propylene glycol were added to the solution, and it was stirred continuously at room temperature for 15 min. Lastly, the gel was kept separately in a cool dark place overnight $\left(10-15^{\circ} \mathrm{C}\right)$ (Maswadeh et al., 2006; Titaley, 2014). The formulated gel was tested for its antimicrobial activity using the agar well diffusion method. The same volume of hand sanitizer commercial product was used to obtain the data for comparison. The gel itself without the addition of LAgNPs was applied as the control.

\section{Statistical Analysis}

All results are expressed as means \pm standard error of the mean or standard deviation (SD). Then, the significant differences were examined by unpaired $t-$ test using SPSS 19 software (USA). A p-value 0.05 was considered as statistically significant.

\section{RESULTS AND DISCUSSION}

\section{Biosynthesis of Liverwort Silver Nanoparticles (LAgNPs)}

The synthesis of LAgNPs was indicated by the change of the liverwort extract color from thick green to brown. The color intensity was increased by time. The liverwort extract that has been synthesized has a solid green color. It is assumed that the constituent of phytochemicals in the liverwort extract reduced the silver metal ions into silver nanoparticles, and it is responsible for the excitation of the AgNPs surface plasmon resonance vibration. Many types of research have reported that the silver nanoparticles show yellowish-brown color from minutes to hours depends on the plant extracts (Moteriya et al., 2014; Paosen et al., 2017; Ramteke et al., 2012).

\section{UV-Vis Spectroscopy of Liverwort Silver Nanoparticles (LAgNPs)}

The first analysis on the characterization of LAgNPs was the UV-Vis spectroscopy to observe the position and shape of the absorption peak as it depends on the particle size, shape, morphology, composition, and dielectric constant of the AgNPs (Jin et al., 2001; Kelly et al., 2003). The results of UVVis spectroscopy analysis of LAgNPs in the wavelength area ranged from 400$700 \mathrm{~nm}$ indicate that the absorption spectrums have a specific range in the formation of silver nanoparticles. The UV-Visible spectra of the nanoparticles obtained have resulted from the reduction of silver ions, which is seen physically from the change in the color of the solution. The measurements using UV-Vis analysis gave an absorbance peak at $422 \mathrm{~nm}$, as shown in Figure 1. The study of the SPR band in the UV-Vis spectra of AgNPs using plants from the Myrtaceae family appeared at wavelength 417 to $462 \mathrm{~nm}$ (Paosen et al., 2017). The maximum absorption was obtained at $462 \mathrm{~nm}$ in a sample of AgNPs from Psidium guajava L. (Moteriya et al., 2014). The presence of AgNPs during the synthesis has been performed by using the UV-Vis spectroscopy. The absorbance in the range of 420 to $450 \mathrm{~nm}$ has been employed as an indicator to confirm the reduction of silver ions to metallic silver nanoparticles (Ali $\boldsymbol{e t}$ al., 2016; Dong $\boldsymbol{e t}$ al., 2014; Karuppiah \& Rajmohan, 2013).

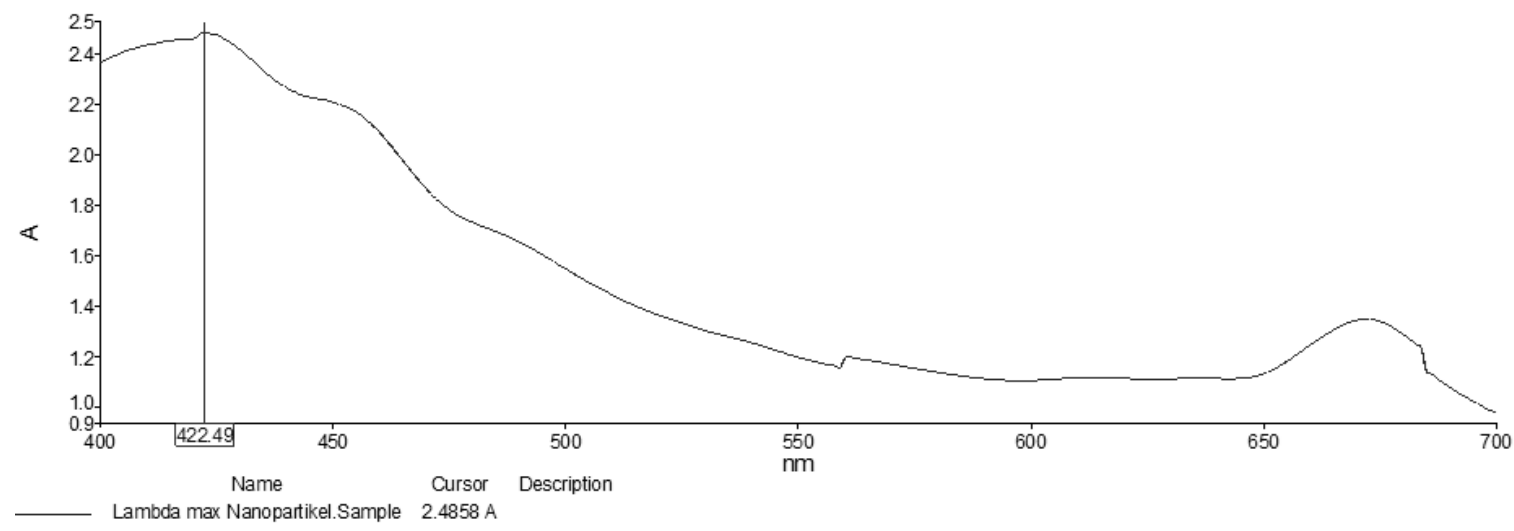

Figure 1 The UV-visible spectrum of biosynthesized Liverwort AgNPs showed a peak at $422 \mathrm{~nm}$

Fourier Transform Infrared (FTIR) of Liverwort Silver Nanoparticles (LAgNPs)

The results of FTIR analysis on LAgNPs is presented in Figure 2. Fourier Transform Infrared (FTIR) analysis was used to identify functional groups that may be involved in the synthesis and reduction of the synthesized AgNPs (Ali $\boldsymbol{e t}$ al., 2016). Figure 2 informs the broad spectrum wavenumber from 3200-3570 $\mathrm{cm}^{-1}$ and peaked at $3435.90 \mathrm{~cm}^{-1}$ showing the hydroxy group, $\mathrm{H}$-bonded $\mathrm{OH}$ stretch, which indicates a hydrogen bond. The stretching vibrations and very weak absorptions in the infrared spectrum in the range $1990-2150 \mathrm{~cm}^{-1}$ shows the presence of isothiocyanate (-NCS). Enzymatic conversion of metabolites called glucosinolates produces many natural isothiocyanates from plants. According to 
the study of Kim and Shin (2015), the isothiocyanate extracted from horseradish root is potential as the candidate of the antibacterial agent against antibioticresistant bacteria. The absorbance in the range of $1590-1650 \mathrm{~cm}^{-1}$ or 1620 $1680 \mathrm{~cm}^{-1}$ and peaked at $1634.04 \mathrm{~cm}-1$ shows the $\mathrm{N}-\mathrm{H}$ indicates the primary amine, $\mathrm{N}-\mathrm{H}$ bend indicates the amide. All these bands indicate the presence of various alkaloids, flavonoids, phenol, tannins, terpenoid, and other phytochemicals in the liverwort extract. The research by Mukhia et al., (2017) on the qualitative tests and thin layer chromatography of Plagiochasma cordatum, Marchantia subintegra and Marchantia emarginata ethanolic extracts have shown phytochemicals such as steroids, tannins, triterpenoids, cardiac glycosides, flavonoids, resins, sugar reduction, amino acids, glycosides, anthraglycosides, arbutin, phenols, and coumarin. Studies show that phenolic compounds present in plants are responsible for antioxidants and other biological activities. Marchantia's primary constituents include triterpenoids, flavonoids, and steroids. Flavonoids include quercetin, luteolin, apigenin, and glycosides (Cao et al., 2007).

Amides are well known as the constituents of plants and many drugs such as paracetamol, penicillin, and LSD, which have a wide range of biologica functions. The research of Huczyński et al. (2012) revealed the salinomycin and its amide derivatives antimicrobial activity against Gram-positive cocci, Gramnegative rods, and yeast-like organisms in vitro. Also, it showed the activity against a series of clinical isolates of methicillin-resistant Staphylococcus aureus and methicillin-sensitive $S$. Aureus. The peak at $603.50 \mathrm{~cm}^{-1}$ and $1016.05 \mathrm{~cm}^{-1}$ shows the disulfides ( $\mathrm{S}-\mathrm{S}$ stretch) and the inorganic compound, respectively.

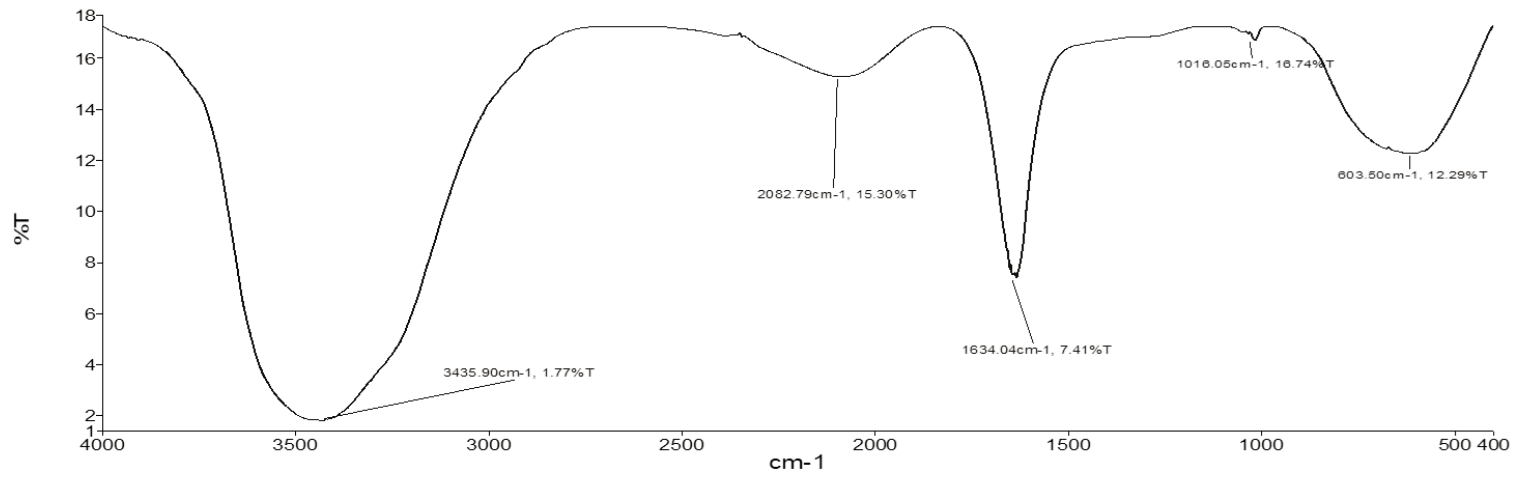

Figure 2 Liverwort AgNPs FTIR spectrum

Scanning Electron Microscopy-Energy Disperse X-ray (SEM-EDX) Analysis of Liverwort Silver Nanoparticles (LAgNPs)

Scanning Electron Microscopic (SEM) aims to determine the morphology, diameter, and ensure that the nanoparticles are formed (Ariyanta, 2016). Based

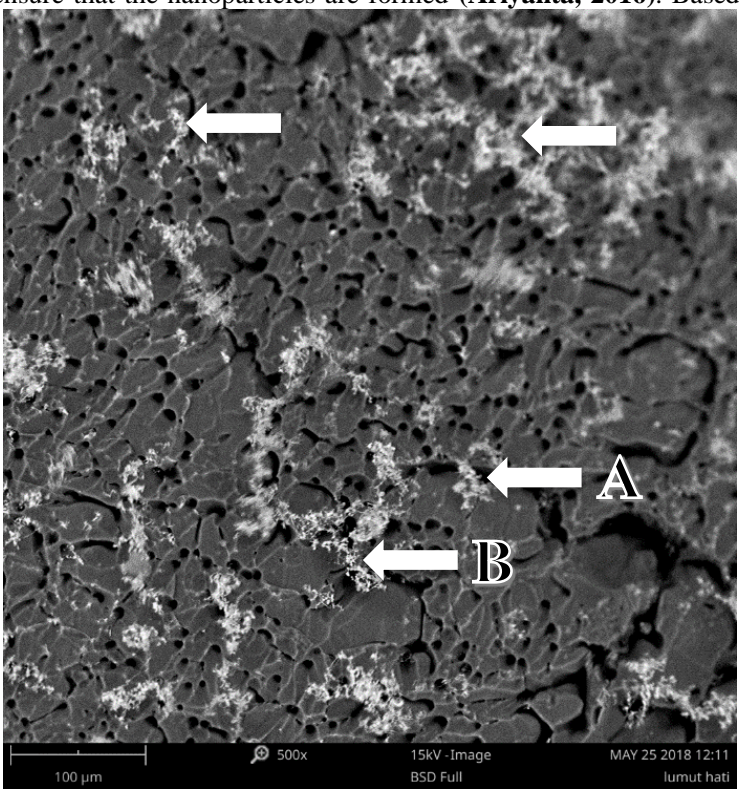

on the observation of the sample of LAgNPs, it has an irregular shape. The following results of SEM analysis are presented in Figure 3. SEM photograph of LAgNPs clearly shows that the synthesized nanoparticles size lies between 0.020 $-0.040 \mathrm{~nm}$

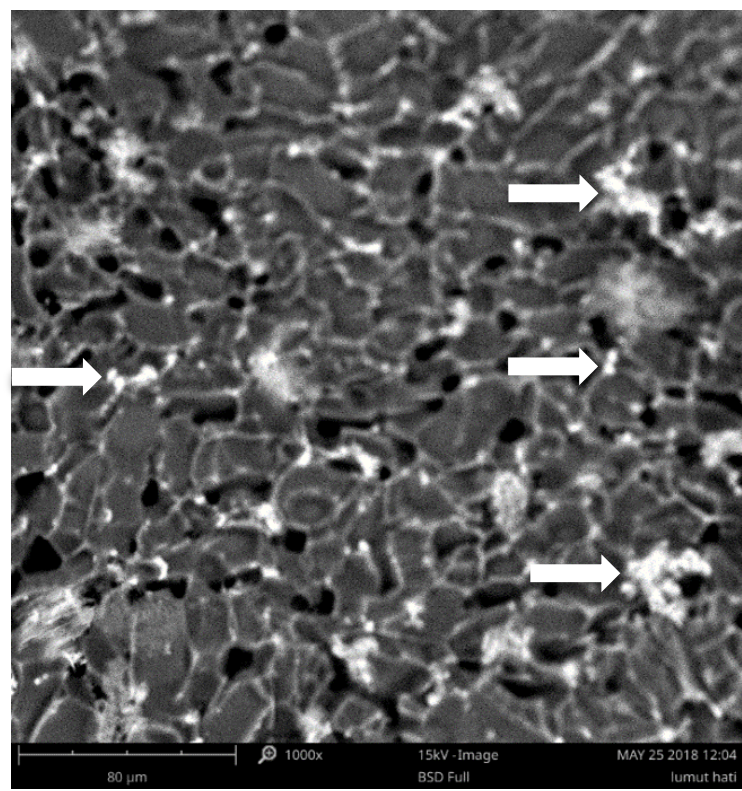

Figure 3 SEM images of liverwort silver nanoparticles (LAgNPs) 500× magnification (left) and 1000× magnification (right)

$(\mathrm{Ag})$. The EDX analysis was done on two spots, i.e., transparent (A) and dark (B) spots. Both spots have the same elements with different weight percentages and certainty above 0.80 for all elements, as shown in Figure 4

The EDX spectroscopy analysis indicates that LAgNPs were produced by showing the degree of certainty. Based on the analysis, the LAgNPs contains several elements, including oxygen $(\mathrm{O})$, carbon $(\mathrm{C})$, Nitrogen $(\mathrm{N})$, and Silver

\begin{tabular}{|c|c|c|c|}
\hline & Weight percentage & & Certainty \\
\hline $\mathrm{O}$ & & $63.3 \%$ & 0.98 \\
\hline C & $20.7 \%$ & & 0.97 \\
\hline $\mathrm{N}$ & $13.0 \%$ & & 0.92 \\
\hline $\mathrm{Ag}$ & $3.0 \%$ & & 0.88 \\
\hline
\end{tabular}

(A)

\begin{tabular}{|c|c|c|c|}
\hline & Weight percentage & & Certainty \\
\hline 0 & & $72.0 \%$ & 0.97 \\
\hline C & $14.8 \%$ & & 0.92 \\
\hline $\mathrm{N}$ & $10.1 \%$ & & 0.85 \\
\hline $\mathrm{Ag}$ & $3.1 \%$ & & 0.76 \\
\hline
\end{tabular}

(B)

Figure 4 The weight percentage of Ag, N, C, O in the transparent spot (A) and dark spot (B) 
Antimicrobial Test of Liverwort Silver Nanoparticles (LAgNPs) and LAgNPs Topical Gel

The method of agar well diffusion was performed to test the antibacterial activities of liverwort Marchantia sp. Silver nanoparticles (LAgNPs) with various concentrations at $25 \%, 50 \%, 75 \%$, and $100 \%$. The clear zone surrounding the wells indicated the successful results of inhibition activity. The diameter of the clear zones was measured, and the average values were calculated. The results of clear zone measurement are presented in table 1 .

Table 1 The diameter of clear zones formed in agar well diffusion method on testing the antimicrobial activities of liverwort Marchantia sp. silver nanoparticles (AgNPs) at concentration 25\%, 50\%, 75\%, and 100\%.

\begin{tabular}{|c|c|c|c|}
\hline Microorganisms & $\begin{array}{c}\text { LAgNPs Concentrations } \\
(\%)\end{array}$ & $\begin{array}{c}\text { The Diameter of Clear } \\
\text { Zones (mm)* }\end{array}$ & $\begin{array}{c}\text { Inhibitory Strength } \\
\text { Criteria }\end{array}$ \\
\hline \multirow{5}{*}{ Escherichia coli } & 0 & $0.32 \pm 0.12 \mathrm{e}$ & Weak \\
\hline & 25 & $11.17 \pm 0.42 \mathrm{~d}$ & Strong \\
\hline & 50 & $11.33 \pm 1.03 \mathrm{c}$ & Strong \\
\hline & 75 & $19.75 \pm 1.13 a$ & Strong \\
\hline & 100 & $16.00 \pm 0.89 b$ & Strong \\
\hline \multirow{5}{*}{ Staphylococcus aureus } & 0 & $0.44 \pm 0.23 \mathrm{e}$ & Weak \\
\hline & 25 & $9.50 \pm 0.41 \mathrm{~d}$ & Moderate \\
\hline & 50 & $10.92 \pm 1.78 \mathrm{c}$ & Strong \\
\hline & 75 & $16.25 \pm 0.54 a$ & Strong \\
\hline & 100 & $15.83 \pm 0.53 b$ & Strong \\
\hline
\end{tabular}

*The values represent mean $\pm \mathrm{SD}(\mathrm{n}=3)$, different letters indicate significant differences between groups $(\mathrm{p}<0.05)$

LAgNPs exhibited the optimum inhibition of both bacterial species at a concentration of $75 \%$, which was more significantly effective in inhibiting the $E$. coli. Using the same concentration, the clear zone diameter against $S$. aureus is smaller than the E. coli. The methanol and chloroform extract from liverwort species Marchantia polymorpha can inhibit the growth of various species of pathogenic bacteria. Also, the $M$. polymorpha extract is fungistatic and bacteriostatic; therefore, it is the potential to be employed in the antimicrobia product formulation (Gahtori \& Chaturvedi, 2011). Mewari \& Kumar (2009) explained that the methanol and flavonoid extracts of $M$. polymorpha exhibit antimicrobial activity against Escherichia coli, Proteus mirabilis, Staphylococcus aureus, and several species of fungi. Relevant research has been conducted by Junairiah et al. (2016), the authors revealed an inhibitory activity using
Dumortiera hirsute ethyl acetate extract against E. coli, S. aureus and Candida albicans by $8.3 \mathrm{~mm}, 10.8 \mathrm{~mm}$, and $10.3 \mathrm{~mm}$, respectively. Determination of the criteria of inhibitory strength is 1 ) very strong with the inhibitory diameter $\geq 20$ $\mathrm{mm}$; 2) strong with diameter from $10-20 \mathrm{~mm}$; 3) moderate with $5-10 \mathrm{~mm}$ in diameter; and 4) weak with clear zone diameter $\leq 5 \mathrm{~mm}$.

According to the results of the antimicrobial test of LAgNPs against two bacterial species, the formulation of topical gel from LAgNPs was performed. Then, the hand sanitizer gel was employed for the agar well diffusion method to test its antimicrobial activity after mixing with other ingredients. The results of the test can be seen in Table 2 .

Table 2 The diameter of clear zones formed in agar well diffusion method for testing the antimicrobial activities of LAgNPs topical gel compared to the hand sanitizer commercial product

\begin{tabular}{|c|c|c|c|}
\hline Microorganisms & Samples & $\begin{array}{c}\text { The Diameter of Clear } \\
\text { Zones (mm)* }\end{array}$ & $\begin{array}{c}\text { Inhibitory Strength } \\
\text { Criteria }\end{array}$ \\
\hline \multirow{3}{*}{ Escherichia coli } & Control & $0.31 \pm 0.11 \mathrm{e}$ & Weak \\
\hline & Hand sanitizer product & $4.00 \pm 2.94 b$ & Moderate \\
\hline & LAgNPs gel & $11.33 \pm 1.03 a$ & Strong \\
\hline \multirow{3}{*}{ Staphylococcus aureus } & Control & $0.34 \pm 0.13 \mathrm{e}$ & Weak \\
\hline & Hand sanitizer product & $7.33 \pm 1.36 b$ & Moderate \\
\hline & LAgNPs gel & $11.00 \pm 0.54 a$ & Strong \\
\hline
\end{tabular}

*The values represent mean $\pm \mathrm{SD}(\mathrm{n}=3)$, different letters indicate significant differences between groups $(\mathrm{p}<0.05)$

Hand sanitizer formulation using LAgNPs produced a light brown gel color and performed a distinctive liverwort aroma. The main ingredient of LAgNPs is Na $\mathrm{CMC}$ as a suspension agent to increase the viscosity and stability of the hand sanitizer product. Na-CMC is a polymer derived from cellulose derivatives that can form a clear mixture of neutral nature. Glycerin and propylene glycol function as moisture retainers or wetting agents that can increase the dispersa capacity of the preparation to prevent dry preparations (Titaley, 2014). The results show that the LAgNPs were significantly more effective in inhibiting the Gram-positive and Gram-negative bacteria compared to the hand sanitizer gel product used in this research.

Antimicrobial compounds can inhibit bacterial growth in various ways such as damage to cell membranes, inhibit cell wall formation, enzyme inactivation, and inactivation of genetic material function to interfere with metabolic processes and bacterial growth. Plant phenolic compounds, for example, flavonoids, can damage cell wall permeability by interacting with bacterial cell membrane proteins through the adsorption process by binding to the hydrophilic part of the cell membrane. These compounds will enter the cell membrane and cause cell protein precipitation. If the permeability of the cell wall is damaged, the cell membrane can undergo lysis (Widyana et al., 2014).

There is the fact that silver nanoparticles (AgNPs) have been studied for their benefit. It proposes many uses, among others, as detectors, catalysts, surface coatings, and antibacterial agents (Ristian et al., 2014). AgNPs synthesis has been carried out by replacing reducing agents with natural bioactive compounds. This technique is considered more environmentally friendly, safe, and effective. Some biomolecules in extracts have been shown to successfully act as reducing agents in the synthesis of AgNPs (Azmi \& Ahyat, 2015; Khatoon et al., 2017) AgNPs have a positively charged ion, $\mathrm{Ag}^{+}$. This positive ion functions to bind to the negatively charged bacterial cell wall, deactivating cellular enzymes, causing changes in bacterial membrane permeability, interferes with the metabolic activity, and leads to protein denaturation (Das $\boldsymbol{e t}$ al., 2010). $\mathrm{Ag}^{+}$ions interact with sulfur-containing proteins in bacterial cell membranes and phosphate backbone in DNA. Therefore, AgNPs could eventually cause bacterial cells to die.
The use of plants in the biosynthesis of nanoparticles is related to the secondary metabolites which have antioxidant activity. Liverworts contain methanol, flavonoids, terpenoids, and chlorophyll compounds. Also, the size of the silver nanoparticles is very influential in determining antimicrobials: the smaller the particle size, the more significant the antimicrobial effect.

This study revealed that as an antibacterial agent against the most common infection-causing bacteria E. coli and S. aureus, liverwort Marchantia sp. silver nanoparticles (LAgNPs) is promising to be formulated as a basic material of hand sanitizer gel. The formulation used in this study excluded alcohol as an ingredient. Therefore, the production of an active, alcohol-free hand sanitizer to fulfill the need of people who have the prone sensitive skin to alcohol-based products is possible.

\section{CONCLUSION}

The biosynthesis of liverwort Marchantia sp. silver nanoparticles (LAgNPs) was successfully performed. It is indicated by the peak of absorbance by UV-Vis spectroscopy analysis at $422 \mathrm{~nm}$. The antimicrobial activity of LAgNPs and LAgNPs hand sanitizer gel was effective in inhibiting the most common Gramnegative (Escherichia coli) and Gram-positive (Staphylococcus aureus) bacteria compared to the commercial hand sanitizer product. FTIR analysis showed that the LAgNPs were stabilized by isothiocyanate and amide, which represents the presence of various phytochemicals in the liverwort extract. The results of this study could be beneficial for the manufacturer in formulating the non-alcoholic hand sanitizer gel product.

Acknowledgments: The research was financially supported by the grant of Students' Creativity Research Program, Ministry of Research, Technology, and Higher Education of Indonesia (Kemenristekdikti) Fiscal Year 2018 through Universitas Negeri Semarang. 


\section{REFERENCES}

ALBERT, N. W., THRIMAWITHANA, A. H., MCGHIE, T. K., CLAYTON, W. A., DEROLES, S. C., SCHWINN, K. E., . . . DAVIES, K. M. 2018. Genetic analysis of the liverwort Marchantia polymorpha reveals that R2R3MYB activation of flavonoid production in response to abiotic stress is an ancient character in land plants. New Phytology, 218(2), 554-566. http://dx.doi.org/10.1111/nph.15002

ALI, Z. A., YAHYA, R., SEKARAN, S. D., \& PUTEH, R. 2016. Green synthesis of silver nanoparticles using apple extract and its antibacteria properties. Advances in Materials Science and Engineering, 1-7. http://dx.doi.org/10.1155/2016/4102196

AMOOAGHAIE, R., TABATABAEI, F., \& AHADI, A.-M. (2015). Role of hematin and sodium nitroprusside in regulating Brassica nigra seed germination under nanosilver and silver nitrate stresses. Ecotoxicology and Environmental Safety, 113, 259-270. https://doi.org/10.1016/j.ecoenv.2014.12.017

ARIYANTA, H. A. 2016. Preparation of silver nanoparticles using the reduction method and its application as an antibacteria of infection-causing microorganisms. Media Kesehatan Masyarakat Indonesia, 10(1), 36-42.

ASAKAWA, Y. 2008. Liverworts-potential source of medicinal compounds. $\begin{array}{llll}\text { Current pharmaceutical design, 3067-3088 } & \end{array}$ https://doi.org/10.2174/138161208786404272

AZMI, A. A., \& AHYAT, N. M. 2015. Green synthesis of silver nanoparticles using rhizhome extract of galangal, Alpinia galangal. Malaysian Journal of Analytical Sciences, 19(6), 1187-1193.

BOLON, M. K. 2016. Hand hygiene: an update. Infectious Disease Clinics 30(3), 591-607. https://doi.org/10.1016/j.idc.2016.04.007

CAO, H., XIAO, J. B., \& XU, M. 2007. Comparison of volatile components of Marchantia convoluta obtained by supercritical carbon dioxide extraction and petrol ether extraction. Journal of Food Composition and Analysis, 20(1), 45-51. DAS, K., TIWARI, R., \& SHRIVASTAVA, D. 2010. Techniques for evaluation of medicinal plant products as antimicrobial agents: current methods and future trends. Journal of Medicinal Plants research, 4(2), 104-111. https://doi.org/10.5897/JMPR09.030

DESIYANTO, F. A., \& DJANNAH, S. N. 2013. Effectivity of hand washing using the hand sanitizer to the bacterial number. Jurnal Kesehatan Masyarakat (Journal of Public Health), 7(2). https://doi.org/10.12928/kesmas.v7i2.1041

DEWI, I. K., \& YUNIANTO, B. 2016. Effectivity test of hand sanitizer from the combination of Ocimum sanctum L. leave extract and Citrus hystrix peel extract Jurnal Kebidanan dan Kesehatan Tradisional, 1(2).

DONG, C., ZHOU, K., ZHANG, X., CAI, H., XIONG, G., CAO, C., \& CHEN, Z. 2014. Semen cassiae extract mediated novel route for the preparation of silver nanoparticles. Materials $\quad$ Letters, 120, 118-121. https://doi.org/10.1016/j.matlet.2014.01.039

GAHTORI, D., \& CHATURVEDI, P. 2011. Antifungal and antibacteria potential of methanol and chloroform extracts of Marchantia polymorpha $\mathrm{L}$. Archives of Phytopathology and Plant Protection, 44(8), 726-731. https://doi.org/10.1080/03235408.2010.516083

HUCZYŃSKI, A., JANCZAK, J., STEFAŃSKA, J., ANTOSZCZAK, M., \& BRZEZINSKI, B. 2012. Synthesis and antimicrobial activity of amide derivatives of polyether antibiotic-salinomycin. Bioorganic \& Medicinal Chemistry letters, 22(14), 4697-4702. https://doi.org/10.1016/j.bmcl.2012.05.081

ISMAIL, I., HAERIA, H., \& AHMAD, F. F. 2017. Potency of coconut peat (Cocos nucifera Linn.) as an antiseptic in a form of topical gel. Jurnal Farmas UIN Alauddin Makassar, 4(4), 146-152.

JIN, R., CAO, Y., MIRKIN, C. A., KELLY, K., SCHATZ, G. C., \& ZHENG, J. 2001. Photoinduced conversion of silver nanospheres to nanoprisms. Science 294(5548), 1901-1903. https://doi.org/10.1126/science.1066541

JUNAIRIAH, J., SA'DIYAH, M., \& SALAMUN, S. 2016. Identification of secondary metabolites and the antimicrobial activity of ethyl acetate extract of Dumortiera hirsuta. Sains \& Matematika, 3(2). https://doi.org/10.23869/bphjbr.16.1.201012

Karuppiah, M., \& Rajmohan, R. 2013. Green synthesis of silver nanoparticles using Ixora coccinea leaves extract. Materials Letters, 97, 141-143. https://doi.org/10.1016/j.matlet.2013.01.087

KELLY, K. L., CORONADO, E., ZHAO, L. L., \& SCHATZ, G. C. 2003. The optical properties of metal nanoparticles: the influence of size, shape, and dielectric environment. ChemInform, 34(16). https://doi.org/10.1002/chin.200316243

KHATOON, N., MAZUMDER, J., \& SARDAR, M. 2017. Biotechnological applications of green synthesized silver nanoparticles. Journal of Nanoscience Current Research, 2(107), 2. https://doi.org/10.4172/2572-0813.1000107

KIM, H.-Y., \& SHIN, I.-S. 2015. Antibacterial activities of isothiocyanates extracted from horseradish (Armoracia rusticana) root against antibiotic-resistan bacteria. Food Science and Biotechnology, 24(3), 1029-1034. https://doi.org/10.1007/s10068-015-0131-y

LARSON, E., GIRARD, R., PESSOA-SILVA, C. L., BOYCE, J., DONALDSON, L., \& PITTET, D. 2006. Skin reactions related to hand hygiene and selection of hand hygiene products. American Journal of Infection Control, 34(10), 627-635. https://doi.org/10.1016/j.ajic.2006.05.289
MASWADEH, H. M., SEMREEN, M. H., \& NADDAF, A. R. 2006. Antiinflammatory activity of Achillea and Ruscus topical gel on carrageenan-induced paw edema in rats. Acta Poloniae Pharmaceutica, 63(4), 277-280.

MEWARI, N., \& KUMAR, P. 2009. Antimicrobial activity of extracts of Marchantia polymorpha. Pharmaceutical Biology, 46(10-11), 819-822. https://doi.org/10.1080/13880200802315725

MOTERIYA, P., PADALIA, H., \& CHANDA, S. 2014. Green biosynthesis of silver nanoparticles using Psidium guajava L. leaf extract and antibacterial activity against some pathogenic microorganisms. Journal of Pharmacy Research, 8(11), 1579-1585.

MUKHIA, S., MANDAL, P., SINGH, D.K., \& SINGH, D. 2017. Study of bioactive phytoconstituents and in-vitro pharmacological properties of thallose liverworts of Darjeeling Himalaya. Journal of Pharmacy Research, 11(5), 490 501

NIU, C., QU, J. B., \& LOU, H. X. 2006. Antifungal bis [bibenzyls] from the Chinese liverwort Marchantia polymorpha L. Chemistry \& Biodiversity, 3(1), 34 40. https://doi.org/10.1002/chin.200626179

PAOSEN, S., SAISING, J., SEPTAMA, A. W., \& VORAVUTHIKUNCHAI, S. P. 2017. Green synthesis of silver nanoparticles using plants from Myrtaceae family and characterization of their antibacterial activity. Materials Letters, 209, 201-206. https://doi.org/10.1016/j.matlet.2017.07.102

RAMTEKE, C., CHAKRABARTI, T., SARANGI, B. K., \& PANDEY, R.-A. 2012. Synthesis of silver nanoparticles from the aqueous extract of leaves of Ocimum sanctum for enhanced antibacterial activity. Journal of Chemistry. 1-7 https://doi.org/10.1155/2013/278925

RISTIAN, I., WAHYUNI, S., \& SUPARDI, K. I. 2014. The study on the effect of silver nitrate concentration to the particle size of silver nanoparticle synthesis Indonesian Journal of Chemical Science, 3(1)

SELVIA, W. R., MULYANTI, D., \& FITRIANINGSIH, S. P. 2015. Formulation of hand sanitizer topical gel of rambutan fruit peel (Nephelium lappaceum L.) and its activity against Escherichia coli and Staphylococcus aureus. Proceeding of Mathematics, Science, and Its Application (KNMSA 2015), ISBN: 978-97999168-1-5. http://repository.unisba.ac.id.

TITALEY, S. 2014. Formulation and the effectivity test of ethanolic extract of Avicennia marina topical gel as a hand antiseptic. Pharmacon, 3(2).

WIDYANA, W., KHOTIMAH, S., \& LOVADI, I. 2014. Antibacterial activities of Octoblepharum albidium Hedw to the growth of Staphylococcus epidermidis and Pseudomonas aeruginosa. Protobiont, 3(2).

XIAO, J., JIANG, X., \& CHEN, X. 2005. Antibacterial, anti-inflammatory and diuretic effect of flavonoids from Marchantia convoluta. African Journal of Traditional, Complementary and Alternative Medicines, 2(3), 244-252. https://doi.org/10.4314/ajtcam.v2i3.31122 